MARKETING AND BRANDING
RESEARCH $\begin{gathered}\text { INDUSTRIAL } \\ \text { MANAGEMENT } \\ \text { INSTITUTE }\end{gathered}$

\title{
Islamic Finance Service Industry and Contemporary Challenges: A Literature Outlook (1987-2016)
}

\author{
Muhammad Asif Khan ${ }^{1 *}$, Muhammad AfaqHaider ${ }^{2}$, Shujahat Haider Hashmi ${ }^{3}$, \\ Muhammad Atif Khan ${ }^{4}$ \\ ${ }^{1,3} \mathrm{PhD}$ Finance Scholar, School of Economics, Huazhong University of Science and Technology (HUST) \\ Wuhan 430074, P.R. China \\ ${ }^{2}$ PhD Finance Scholar,School of Economics, Shanghai University, Shanghai200444, P.R. China \\ ${ }^{1,4}$ University of Kotli, AJK, I.R. Pakistan
}

\begin{abstract}
Keywords:

Islamic finance service industry, Challenges, Shariah Compliance, legal framework

Correspondence: khanasif82@hotmail.com

Embryonic Islamic banking industry has documented marvellous growth worldwide since inception; stimulated sound rooted western banking to inculcate and include Shariah driven lucrative products and services as an integral part of corporate segment. Research to date has revealed its unique features and ethos, yet it has to overcome multifarious global impediments. The focus of this study is to encapsulate the enormous challenges Islamic finance service industry has encountered during last three decades. We find the arguments such as complex regulatory and supervisory issues; absence of uniform reporting standards; prudential challenges; misconception among western society pertaining to Islamic banking; scant financial instruments and concurrent money and capital markets; fierce compaction by western banking; lack of consensus among Shariah Scholars; and central governing body that are precarious challenges among others. Therefore, policy makers need to constitute an integrated central regulatory body to congregate speckled Islamic banking practices and to foster the underlying philosophy of Sharia compliance operation along with synchronized and unified standardized worldwide.
\end{abstract}

\section{Introduction}

Islamic finance, although nascent, related to diversified counterpart western finance, gained reasonable attention among research and Shariah scholars due toits underpinned unique principles such as being equity based, backed up by assets, and being viable, ethical, social, 
and ecologically responsible. The prominent feature that differentiates Islamic finance from conventional one is the emphasise it put forth on social welfare and financial inclusion. Like other social sciences fields, Islamic finance is guided by set of principles,namely interest free economic transaction, materiality based finance (asset-backed), exclusion of unethical and immoral business activities (e.g. alcoholic operations), and returns tagged with associated risk.The emergence of Islamic finance as an effective financing tool across the globe irrespective of religion doctrine has firmly penetrated in universal financial system accompanied by the most remarkable features of poverty alleviation through microfinance and joint prosperity booster.

The Islamic finance service industry (IFSI) has reported an annual growth rate between 10 to $12 \%$ over last decade, and Shariah acquiescent financial assets are currently estimated roughly around 2 trillion USD encompassing bank as well as non-bank financial institutions, money and capital markets and that of Takaful (Islamic insurance).A noticeable aptitude among non-Muslim nations (United Kingdom, South Africa, Luxembourg, and Hong Kong) regarding Islamic finance has been observedthat resulted in faster growth of typical Islamic finance assets in these countries compared with conventional industry assets. Islamic finance boosts economic growth through financial sector development and least susceptible in financial crises. It ensures financial stability relied upon its conservative liquidity policies and IFSI was least affected by 2008 global financial crises because Shariah laws do not permit speculative and unethical instruments like complex derivatives (SWAP, CDOs).

Similar to Standard and Poor (S\&P) conventional indices S\&P set of Shariah indices provides useful information to investors with respect to securities comply Shariah compliance. Every member of Shariah index family represents comprehensive information about various investment portfolios with daily, monthly, and yearly frequency for the respective index. The S\&P Shariah indices returns for whole Shariah family are exhibited in Figure 1. Roughly, around 20 global Shariah indices are presented graphically in terms of last year returns (from $17^{\text {th }}$ October 2016 to $17^{\text {th }}$ October 2017). This graphical depiction illustrates the progress of Shariah compliant securities in internal financial markets, measure as changes in daily return. Out of 20 indices 14 (70\% of total) closed with positive outlook, while only 6 $(30 \%)$ closed with negative change. The indices with dropped return on last trading day not necessarily mean their below benchmark performance, in fact looking objectively over whole year return patterns, a clear upward trend indicates Shariah securities acceptability worldwide. This growing sentiment of Shariah indices signals that IFSI has penetration in international finical markets and gains favourable momentum. It assures that there is something for investors in Shariah compatible securities and expected to have even more bright future. Figure 1 presents S \& P Shariah indices return. 

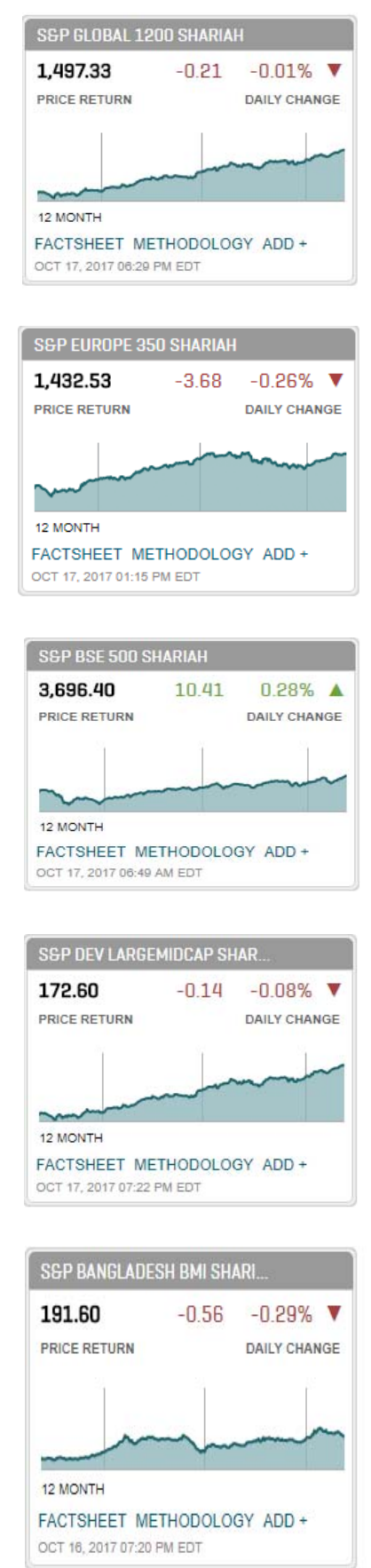
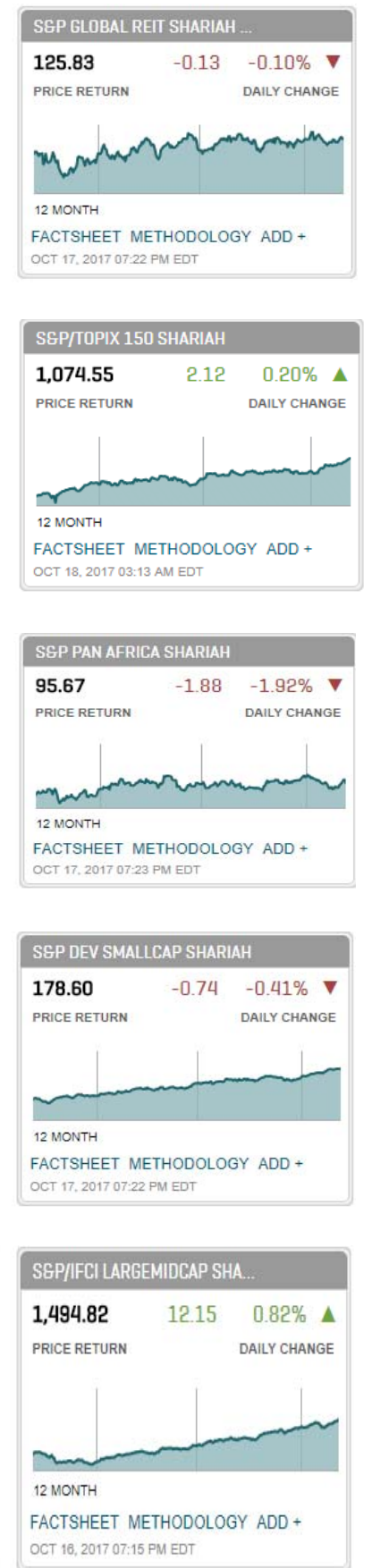
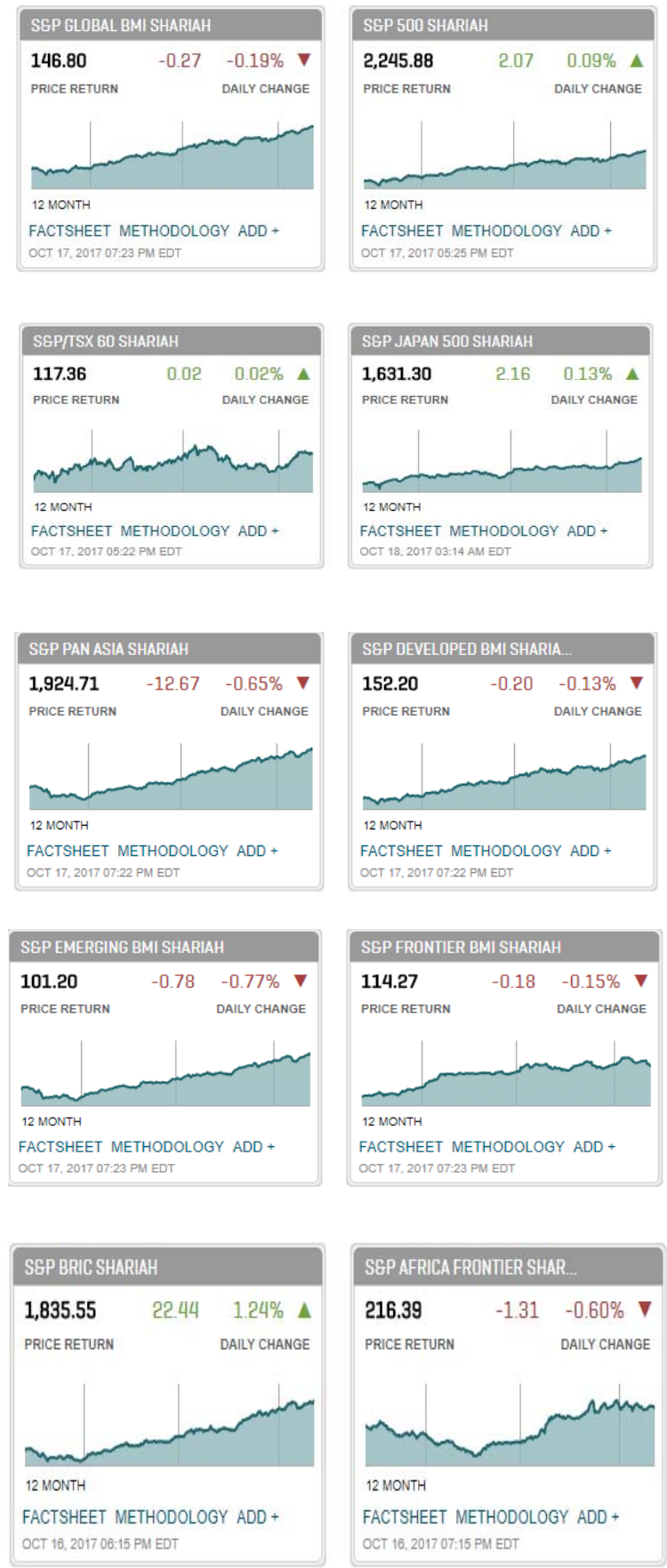

Figure 1. S \& P Shariah indices return

Source: S\&P official Webisite (https://www.spindices.com/index-family/shariah/sp-shariah)

Islamic Finance Country Index (IFCI) is a composite index and ranks countries with respect to IFCI scores during a particular year; this score for year 2015 and 2016 is presented in Table 1. Since 2011, Iran has been the leader of Islamic Finance Service Industry (IFIS), but in 2016 this position is captured by Malaysia with an improvement from second position. Out of 14 Islamic countries 7 (Malaysia, Indonesia, Qatar, Pakistan, Bangladesh, Egypt, and Jordan) has improved one-step up, 2 deteriorated by one (Iran and Turkey) and 2 (Bahrain and Sudan) by two grades, respectively; while 3 maintain previous position include Saudi Arabia, UAE, and Kuwait. The GIFR reveals that Islamic project finance is flourishing more in GCC 
due to capital projects including oil and gas extraction, subsequent transportation and refinery processes. Islamic microfinance has emerged as rapidly growing market as well as poverty alleviation, servicing around 1.28 million customers in this important segment. Like project finance and microfinance, takaful (Islamic insurance) expanded four times in last few years. Evidently, it is indeed a fast growing industry, yet it needs few decades to stand at parity with conventional counterpart (Global Islamic Finance Report, 2016).

Table 1 represents the IFCI Score for Year 2015-2016 (top 14 Countries are shown here).

Table 1

The IFCI Score for Year 2015-2016

\begin{tabular}{|c|c|c|c|c|c|}
\hline Countries & $\begin{array}{c}\text { IFCI Score } \\
2016\end{array}$ & $\begin{array}{c}\text { IFCI Score } \\
2015\end{array}$ & $\begin{array}{c}\text { IFCI Rank } \\
2016\end{array}$ & $\begin{array}{c}\text { IFCI Rank } \\
2015\end{array}$ & Changes \\
\hline Malaysia & 77.77 & 77.09 & 1 & 2 & 1 \\
\hline Iran & 77.39 & 77.93 & 2 & 1 & -1 \\
\hline Saudi Arabia & 66.98 & 66.94 & 3 & 3 & 0 \\
\hline United Arab Emirates & 36.68 & 34.57 & 4 & 4 & 0 \\
\hline Kuwait & 35.51 & 33.40 & 5 & 5 & 0 \\
\hline Indonesia & 24.21 & 22.45 & 6 & 7 & 1 \\
\hline Qatar & 22.02 & 19.04 & 7 & 8 & 1 \\
\hline Bahrain & 21.90 & 23.93 & 8 & 6 & -2 \\
\hline Pakistan & 18.89 & 13.38 & 9 & 10 & 1 \\
\hline Bangladesh & 16.14 & 11.11 & 10 & 11 & 1 \\
\hline Sudan & 14.04 & 14.24 & 11 & 9 & -2 \\
\hline Egypt & 9.02 & 7.34 & 12 & 13 & 1 \\
\hline Turkey & 8.95 & 8.83 & 13 & 12 & -1 \\
\hline Jordan & 7.98 & 3.98 & 14 & 15 & 1 \\
\hline
\end{tabular}

Figure 2 shows the size and growth prospects of IFSI, both historical performance (20072016) and potential future forecast for 2020. Overall trend depicts positive performance in terms of size and growth over the period and expected to grow event with a sharp pace. Since 2007, assets of IFCI have grown up remarkably with positive prospects; however, there are some factors slowed down these momentum including political conflicts among some of the Muslim world countries, Middle East in particular, and ever-lowest oil prices in GCC where IFCI are major financial market players. In addition, it is argued that western enthusiasm is curtailing towards Islamic financial instruments in general. 


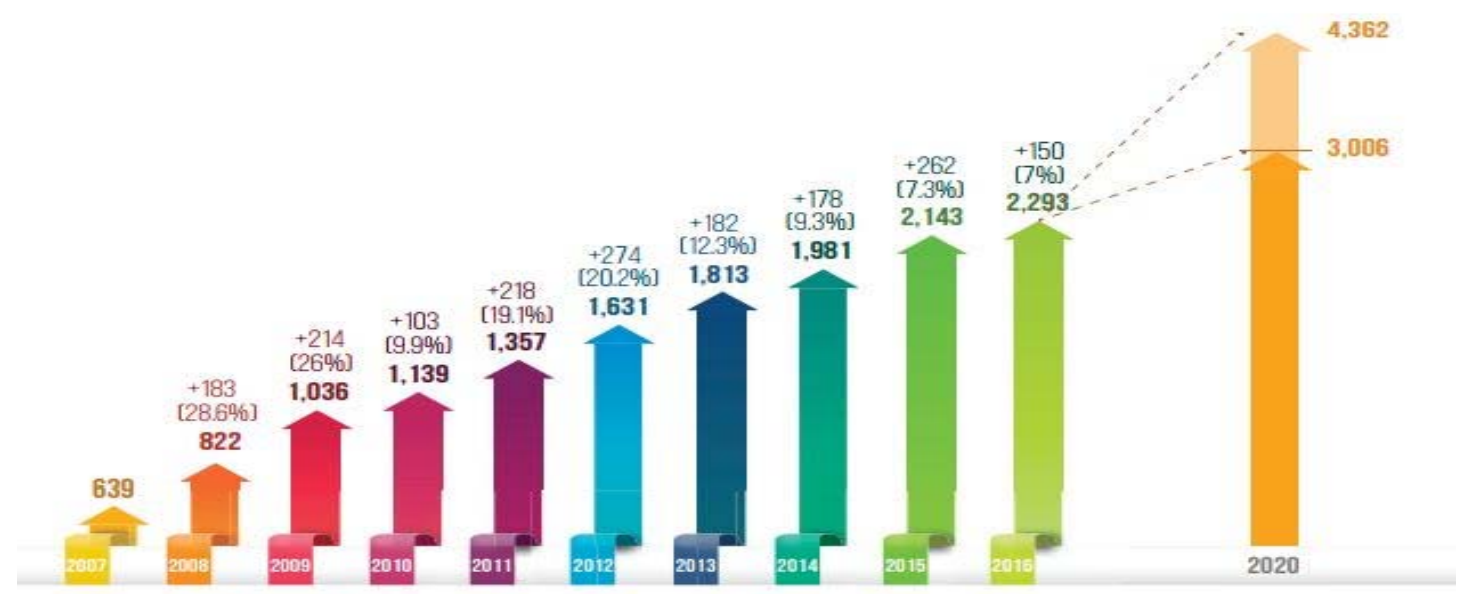

Figure 2. IFSI size and growth prospects, 2007-2016 (all fig. in US billion dollar)

Source: Global Islamic Finance Report (2017)

Figure 3 exhibits the position of Sukuk finance from 2012-2016. Similarly, Sukuk (Islamic bond) financing proportion has also declined in last five years (see Figure3). The left half of Figure 2 presents the proportion of Sukuk financing and Malaysia captures $47 \%$, the highest share of such financing; this shows the depth of Islamic financial market in Malaysia as it is ranked at top (see Figure 2). The GCC member countries are second highest Sukuk finance generator with $26 \%$ followed by Indonesia, UAE, and other with around 10\% participation. The right half of facing figure gives snapshot of Sukuk finance patterns. A downward pattern is observed from 2012-2015 with a slight rise during 2016. Aggregately, it has condensed from 137.16 to 74.8 US billion dollars from 2012 to 2016.

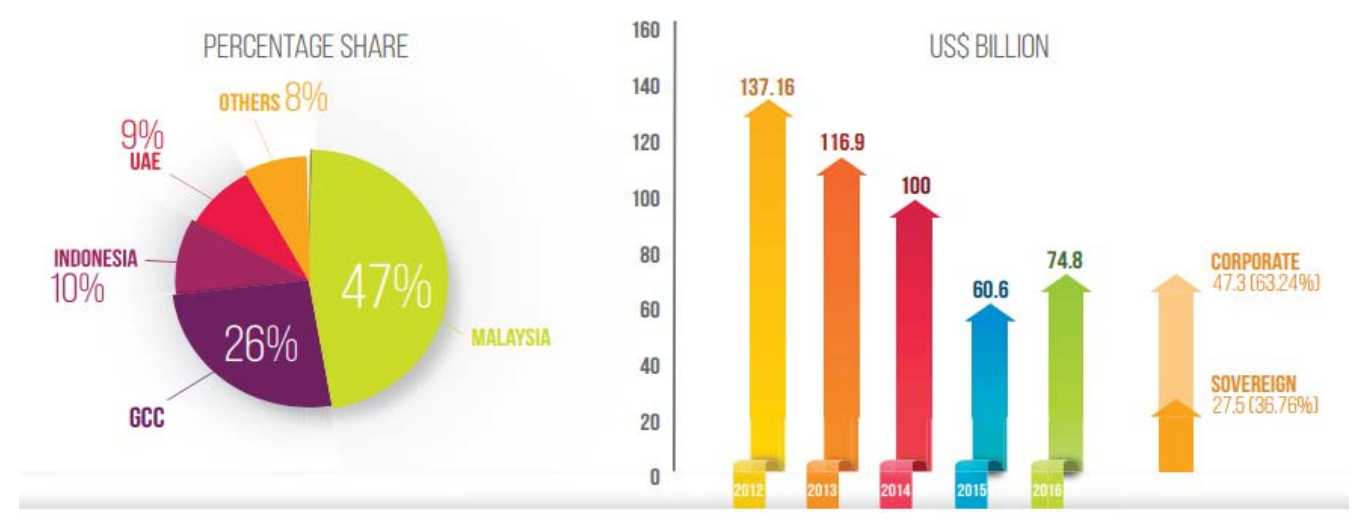

Figure 3. Position of Sukuk finance from 2012-16

Source: Global Islamic Finance Report (2017)

The facts and figures in above sections indicate a growing momentum of IFSI worldwide; however, the problems and challenges move parallel, in prevailing global environment where competitors are sound rooted, spread around the globe with mature age and diversified technological resources. The purpose of this paper is to highlight the key problems and challenges IFCI has faced during last three decades (1987-2016). 


\section{Key Problems and Challenges to IFSI}

This descriptive study categorizes these problems and challenges in three clusters, each cluster accounts for ten years' span followed by conclusion and recommendation afterwards.

\section{First Decade (1987-1996)}

With respect to Malaysia, we found that Shariah compliant businesses are lacking Shariah framework; however, there is scope to expand the business environment by incorporating existing legal framework. This is assumed to present Malaysia as a global hub for Islamic finance products; moreover, it is considered as a destination for Shariah-complaint franchise businesses at the global level (Oseni, 1987). As far as short-term financing is concerned, IFSI is doing well, yet is has shortfalls in terms of expertise to cater long-term financing mechanism. Moreover, secondary capital market for Islamic financial products and stringent Shariah laws are among other challenges (Ariff, 1988). Although the idea behind Islamic economy is very viable but it has confrontation of insufficient institutional framework support, lack of effective leadership, and intellectual learning centres to mobilize resources (Siddiqi, 1989). Islamic banks are hindered by deficiencies like absence of interbank network missing Islamic accounting standards and shortage of work force (Pervez, 1990).

The focus of Muslim economist group has been towards developing a theoretical framework, rather they need to frame policies consistent with contemporary problems economy faces and real life data driven principles for Islamic economy management (Khan, 1991). Financing mechanism during growth phase for firms and sole proprietors in particular is a big challenge in context of Islamic finance, as the sensitive nature compromises the ownership of these stakeholders and demand attention of policy makers (Abod, Ghazali \& Agil, 1992). Muslim countries face even more severe nature of problems compared with that of industrialized countries; resources at their disposal are even scarcer. Removal of their macroeconomic and external imbalances requires a reduction in aggregate demand. Realization of the Maqaidrequires the opposite of this: Increased spending for a number of neglected but essential objectives. How to resolve this conflict is the challenge that Muslim countries face. They cannot respond to this challenge successfully by adopting strategies that have failed. A failed strategy cannot but lead to failure. Muslim countries are required to device own strategy that may help allocation of limited resources in compliance with Shariah guidelines.

Although Islamic economic system faces challenges like equitable dissemination of taxes and wealth, cartel, unlawful ownership, and eliminating interest, yet it needs to rebuild the real image of Islamic economy among western people as they think otherwise (BinSayeed, 1995). Consistently, under Islamic economy, commercial transactions are performed in more specific manner; unique nature of issues poses a chunk of problems for Islamic institutions. In addition, functioning in diverse legal, political, economic, social, and religious environment are thoughtful issues for complex Islamic banking system (Al-Omar \& Abdel-Haq, 1996). 


\section{Second Decade (1997-2006)}

In a country like Singapore, where Muslim community is in minority, Islamic banking culture has different degree of influence on both Muslims and non-Muslims with respect to the level of awareness about afflux of Islamic banking (Gerrard \& Cunningham, 1997). The most serious challenges the IFSI faces are to build moderate institutional setup, rising competition, demand to cope with capital project financing and research and development aspects; following this, there is need to enlarge the size and volume of IFSI.Furthermore, establishing and distinguishing fixed and variable financing mode, equity related instruments and polices regarding legal framework are continuation of these issues (Iqbal, A mad,\& Khan, 1998).In the absence of efficient money market for Islamic financial instruments that may suit budgetary and government debt manoeuvres, the IFSI profit potential has declined due to risk of liquidity management (Sundararajan, Marston, \& Shabsigh, 1998).

There is a demand to develop such financial instruments which can be traded globally and substantial secondary markets are available for them. This also raise the question of accounting principles for such instruments to assure transparency as well as establishment of interbank market (Sarker, 1999). Today's modern banking relies on highly sophisticated technological products; this has raised big challenge for IFSI. The problem is not only in the adoption of technology but also in the preparation of a suitable environment that will enable them to utilize the technology in order to compete effectively. The globalization also imposes a challenge on the Shariah authorities in Islamic banks in the issuing of Fatawah required in the rapidly evolving international financial markets (Al-Raji, 1999). Regulatory complexities and branding of Islamic products are two prominent issues confronting Islamic financial institution in West and UK (Wilson, 1999).

Complying with the Shariah regulation pertaining to monetary policy, taking loans from central bank as interest is payable on such loans and no separate regulatory and supervisory guidelines for the Islamic banks demand immediate policy action (Sarkar, 2000). Unavailability of financial markets for trading Islamic financial instruments while competing with counterpart is a considerable factor. The growth is tagged with innovative products, which may be per chosen by individual as per respective religious belief and economical needs (Zaher\& Hassan, 2001). Under Islamic philosophy of doing business, there are distinct challenges to classify, measure, monitor and control the fundamental risk associated with financial instruments. As IFSI is expected to compete globally, it has to address this important segment of risk management effectively and efficiently, possibility by developing optimal regulatory framework and institutional arrangements (Sundararajan \& Errico, 2002).

The state is supposed to play the role of facilitator in case of financial services. To this end, it requires to regularly observe and upgrade the legal and regulatory environment in which the industry acts without stifling independent initiatives or disorienting it through constant, poorly transparent changes. The state should avoid involving itself in various promotional activities of financial matters. Correspondingly, public and businesses should also abstain from depending upon state as benevolent father (Grais \& Kantur, 2003). The IFSI with challenges related to instruments, regulations, financial markets, and awareness of the concept of Islamic finance must found a viable solution to these issues which hinder its progress. Perhaps the most problematic aspect is the image and perception of Islamic financial institutions in the global market (Nasim, 2003). 
In UK, potential clients and heterogeneous clients are the major problems IFSI faces. Apparently, the establishment of Al-Baraka in UK makes equivalent institutions have the sense that Islamic banking can operate under nonbanking regulations. Furthermore, supervisory sprints, conventional banking competition, and shortage of sufficient well skilled staff have worsened the situation even more (Karbhari, Naser, \& Shahin, 2004). In Bangladesh, policies are required to develop inter-bank money market similar to conventional one; Shariah supervisory board should be activated and Islamic banking act should be enacted (Sarker, 2005). To resolve the number of challenges IFSI face is an unsettled fiqha issue. There is a need to address this issue, thinking someway differently by setting aside the current framework and to sort out new priorities. Even within the framework, there are some techniques which are yet to be fully tested (Siddiqi, 2006).

\section{First Decade (2007-2016)}

Risk and liquidity management practices for Islamic firms are mounting challenge that is in particular due to unavailability of Islamic financial instruments. On other hand, Islamic bond has raised question for Islamic scholar to clearly decide whether this instrument is complying the rules of Sharia or not:This can add another layer of complications for regulators (Ainley, Mashayekhi, Hicks, Rahman,\& Ravalia, 2007). The absence of fully integrated and fairly organised network among IFSI and heterogeneous nature of financial products offered by this industry are the issues to be resolved to formulate successful strategies to attract customer worldwide (Garas\& Manama, 2007). The structure for investment, financing, liquidity management, transparent and efficient money, and capital market for Islamic financial instruments, accounting standards, and disparity among Shariah scholars are hurdle in the way of uniform regulatory framework (Hesse, Jobst,\& Solé, 2008). Similarly, it is noticed that Islamic rural financial banks are unable to offer dynamic and efficient services (Seibel, 2008).

Various types of risks associated with Islamic financial instruments, liquidity management strategies, limited nature of secondary market for such instruments, variant interpretation of Islamic rules, and stationary process of Islamic products development are core issues for IFSI.Shaukat, Zafarullah, and Wajid (2009), found that in Pakistan Islamic financial intuitions are lacking in the infrastructure of telecommunication which led towards slower growth. Ahmed (2010), documented that corporate governance, transparency and discipline in financial markets and lack of consensus and diverse interpretation for same problem by every bank Shariah board are among main challenges for IFSI. Consistently, Khan and Porzio (2010), have identified that contracts in Islamic finance, management of assets, Islamic bank customer care, and competition by conventional sector banking are prominent issues.

Sadaqat, Ali, and Farhan (2011), have empirically found that for Pakistani Islamic banks the major challenge is management of liquidity risk. However, Hanif (2011) listed three challenges Islamic banks faced, namely Shariah compliance in the presence of non-Islamic banking with its strong network, catering the industrial and financial requirements, and removing the mind-set of Muslim community about misconception about Islamic banking (they consider it duplicate form of conventional practices under the umbrella of Shariah). Samat (2012), reported misconception about Islamic finance; ununiformed Shariah viewpoints, complex documentation, fierce competition, and brand recognition are serious 
challenges faced by Islamic finance. Young (2013) argued that there is a need to transform regulatory framework for Islamic banking to optimize the riskiness in retail banking.

Shah, Raza, and Khurshid (2012) claimed that the big problem is the variety of governing bodies (separate Shariah board for every Islamic bank) and absence of harmony among Shariah scholars designated with the responsibility to provide ruling for Islamic products. Ullah and Chowdhury (2013) declared that in Bangladesh stiff competition with wellnetworked non-Islamic banks, promoting allocating and distributional efficiency from all respect along with profit generating capacity are relatively worse challenges for IFSI.According to Aris et al., (2013), IFSI need to be competitive in terms of sufficient and innovative instruments to play at the level of conventional competitors. These products must have enough capacity to comply with Shariah requirements as well as legislative measure of the respective nation. Without proper regulations, policies, and enforcement, the implication is normally transferred to the consumer. Ismal (2013) demonstrate that there is no doubt that IFSI manage the liquidity very well to tackle challenges like low market share of industry, insufficient human capital and development of niche of products to expand at right horizon.

Karim and Archer (2013) professed the role of Shariah as backbone for IFSI to assure credibility and integrity. The non-compliance element will not only impact the confidence level related to IFI's shareholders and public but in addition to Shariah non-compliance risk and associated reputational risk may further expose IFIs to different other losses. SeyedJavadin, Raei, Safari, and Iravani (2014) summarized the lack of determination among top level management, inadequate rules with adequate supervision, non-competitiveness with non-Islamic operations and unawareness among customers and general public are vital challenges among rest. Yunusa and Nordin (2015) have noticed two categories of challenges includingthose that emanate from non-Muslim believers and the categories which are from within the boundaries of Islam (not in line with the actual teachings of the Shariah). The mentioned challenges regarded religious because of their direct linkage with religious beliefs.Abu-Qalbein (2016) has conducted the structured interviews of some experienced officials of Islamic financial institutions to find the major challenges Islamic institutions face in GCC. The findings demonstrate that firstly, people are unable to distinguish between Islamic and non-Islamic banking and secondly, there is lack of standardization of Islamic products.

\section{Discussion and Conclusion}

Based upon the literature reviewed in above section the study found following major challenges encountered by IFSI worldwide during the study period; the challenges involve the requirement of specific Shariah compliance and central uniform regularity framework, unavailability of Islamic Financial markets (both money and capital markets), unavailability of diverse and standardize Islamic financial instruments, liquidity management challenges; heightened western banking competition, lack of consensus among Shariah scholars, required Islamic financial reporting standards and accounting principles, technological and innovative Islamic finical products, misconception among western community about Islamic banking and also misconception among a group of Muslims as they perceive it mere duplication of conventional banking, and scarcity of skilled and competent staff. 
This is utmost desirable for Shariah scholars to develop consensus among the conflicting and ambiguous matters regarding authenticity of various instruments used by IFSI. Looking objectively to devise standardized and fully integrated regulatory framework to be adopted and monitored would be the most feasible solution. Concurrently, establishment of clear rules for conduct of audit of all IFSI is need of time that will potentially promote the reliability and integrity of the financial statements periodically compiled and published by IFSI. The IFSI can outperforms conventional counterpart with synchronization among professionals, practitioners, and religious scholars to establish a platform where all major issues may be discussed and resolved.

This study aimed at highlighting the core problems and challenges being faced by IFSI over last three decades. As this study is descriptive in nature, it offers valuable future direction for potential extensions; a comprehensive extension can be used to seek the optimum solution to the highlighted problems and challenges. There is another substantial area to replicate this methodology on congenital and geographical basis as every geographical area has embedded unique theology and societal approach to Islamic banking and finance. Micro approach may also be a better choice to bifurcate these challenges into homogenous groups and therefore, find optimal solution.

\section{References}

Abod, G. S., Ghazali, A., \& Agil, O. S. (1992). An Introduction to Islamic Finance. Quill Publishers.

Abu-Qalbein, A. M., (2016). Challenges of Islamic banking in Gulf Corporation Council. European Journal of Business \& Management, 8(6), 177-185.

Ahmed, A. M. E. T. (2010). Islamic banking: How to manage risk and improve profitability. NJ: John Wiley \& Sons.

Ainley, M., Mashayekhi, A., Hicks, R., Rahman, A., \& Ravalia, A. (2007). Islamic finance in the UK: Regulation and challenges. The Financial Services Authority (FSA), London.

Al-Omar, F., \& Abdel-Haq, M. (1996). Islamic banking: Theory, practice and challenges. London: Zed Book Ltd.

Al-Raji, A. S. (1999). Islamic Banks Technology and Global Challenges and Opportunities. Proceedings of the Third Harvard University Forum on Islamic Finance, Center for Middle Eastern Studies, Harvard University, 177-178.

Ariff, M. (1988). Islamic banking. Asian-Pacific Economic Literature, 2(2), 48-64.

Aris, N. A., Othman, R., Azli, R. M., Sahri, M., Razak, D. A., \& Rahman, Z. A. (2013). Islamic banking products: Regulations, issues and challenges. Journal of Applied Business Research (JABR), 29(4), 1145-1156.

BinSayeed, K. (1995). Western dominance and political Islam: Challenge and response. Albany: State University of New York Press.

Garas, S. N., \& Manama, B. A. (2007). Internationalization of Islamic financial institutions: Challenges and paths to solution. Thunderbird International Business Review, 49(2), 225-249.

Gerrard, P., \& Cunningham, J. B. (1997). Islamic banking: A study in Singapore. International Journal of Bank Marketing, 15(6), 204-216.

Grais, W., \& Kantur, Z. (2003). The changing financial landscape: opportunities and challenges for the Middle East and North Africa. World Bank Policy Research Working Paper, (3050). World Bank, Washington, DC. Retrieved from https://openknowledge.worldbank.org/handle/10986/18188 License: CC BY 3.0 IGO.”

Hanif, H. (2011). Differences and similarities in Islamic and conventional banking. International Journal of Business \& Social Science, 2(2), 166-175.

Hesse, H., Jobst, A., \& Solé, J. (2008). Trends and challenges in Islamic finance. World Economics, 9(2), 175-193.

Iqbal, M., A mad, A., \& Khan, T. (1998). Challenges facing Islamic banking. Jeddah, Saudi Arabia: Islamic Research and Training Institute, Islamic Development Bank. 
Ismal, R. (2013). Islamic banking in Indonesia: New perspectives on monetary and financial issues. Singapore: John Wiley \& sons.

Karbhari, Y., Naser, K., \& Shahin, Z. (2004). Problems and challenges facing the Islamic banking system in the west: The case of the UK. Thunderbird International Business Review, 46(5), 521-543.

Karim, R. A. A., \& Archer, S. (2013). Islamic finance: The new regulatory challenge.Singapore: John Wiley \& sons.

Khan, A. M. (1991). The future of Islamic economics. Futures, 23(3), 248-261.

Khan, F. \& Porzio, M. (2010). Introduction. In M. F. Khan \& M. Porzio (Eds.), Islamic banking and finance in the European Union: A challenge (pp. 1-7), Cheltenham, UK: Edward Elgar Publishing Limited.

Nasim, F. (2003). Prospects of Islamic banking: Legal and other challenges and issues. Cardiff Law School.

Oseni, U. A. (1987). The law and regulation of franchising in Malaysia's Islamic finance industry: Problems, prospects and policies. Global Journal Al-Thaqafah, 6(2), 37-45.

Pervez, I. A. (1990). Islamic finance. Arab Law Quarterly, 5(4), 259-281.

Sadaqat, S., Ali, K., \& Farhan M. (2011). Liquidity risk management: A comparative study between conventional and Islamic banks of Pakistan. Interdisciplinary Journal of Research in Business, 1(1), 35-44.

Samat, Z. (2012). Islamic Banking: The Lessons and Challenges Strictly Private \& Confidential in Malaysia \& Beyond. Bank Islam, Kuala Lumpur. Retrieved from www.bankislam.com.my/en/documents/shariah/presentationtofstep-dsz.pdf on $15 / 10 / 2017$.

Sarkar, A. A. (2000). Regulation of Islamic banking in Bangladesh: Role of Bangladesh bank. International Journal of Islamic Financial Services, 2(1), 67-72.

Sarker, A. A. (2005). Islamic banking in Bangladesh: achievements and challenges. Journal of Islamic Economics and Finance, 1(1), 45-59.

Sarker, M. A. A. (1999). Islamic banking in Bangladesh: performance, problems, and prospects. International Journal of Islamic Financial Services, 1(3), 15-36.

Seibel, H. D. (2008). Islamic microfinance in Indonesia: The challenge of institutional diversity, regulation, and supervision. SOJOURN: Journal of Social Issues in Southeast Asia, 23(1), 86-103.

Seyed-Javadin, S. R., Raei, R., Safari, M., \& Iravani, M. J. (2014). An explanatory analysis to identify and prioritize the challenges of Islamic Banking implementation: The case of IR Iran. International Letters of Social \& Humanistic Sciences, 24, 45-55.

Shah, F. S., Raza, M. W., \& Khurshid, M. R. (2012). Islamic banking controversies and challenges. Interdisciplinary Journal of Contemporary Research in Business, 3(10), 1018-1026.

Shaukat, M., Zafarullah, M., \&Wajid, R. A. (2009). Information technology in Pakistan: An Analysis of problems faced in IT implementation by Pakistan's banking and manufacturing companies. Pakistan Journal of Social Sciences (PJSS), 29(1), 13-22.

Siddiqi, M. N. (1989). Islamizing economics. In Toward Islamization of disciplines (pp. 253-261). Herndon, VA: International Institute of Islamic Thought.

Siddiqi, M. N. (2006). Islamic banking and finance in theory and practice: A survey of the state of the art. Islamic Economic Studies, 13(2), 1-48.

Sundararajan, V. Marston, D., \& Shabsigh, G. (1998). Monetary operations and government debt management under Islamic banking (EPub). IMF working paper, WP/98/144, Washington DC, USA.

Sundararajan, V., \& Errico, L. (2002). Islamic financial institutions and products in the global financial system: Key issues in risk management and challenges ahead. Working Paper, International Monetary Fund, Monetary and exchange affairs department, Washington, D.C. 02/192, 27.

Ullah, M. M., \& Chowdhury, M. S. A. (2013). Prospects of Islamic Banking in Bangladesh. Proceedings of $3^{\text {rd }}$ Asia-Pacific Business Research Conference, Kuala Lumpur, Malaysia.

Wilson, R. (1999). Challenges and opportunities for Islamic banking and finance in the West: The United Kingdom experience. Thunderbird International Business Review, 41(4/5), 421-444.

Young, E. (2013). World Islamic Banking Competitiveness Report 2013. Mena: Ernst \& Young. 
Yunusa, M., \& Nordin, N. B. (2015). Religious challenges of Islamic banking in Nigeria. International Journal of Academic Research in Business \& Social Sciences, 5(4), 46-66.

Zaher, T. S., \& Hassan, K. (2001). A comparative literature survey of Islamic finance and banking. Financial Markets, Institutions \& Instruments, 10(4), 155-199. 